\title{
Pengaruh Strategi Pembelajaran Multirepresentasi dengan Pendekatan Conceptual Problem Solving terhadap Kemampuan Pemecahan Masalah dan Kemampuan Representasi
}

\author{
Leonardus Hendra Aha $^{1}$, Muhardjito ${ }^{1}$, Sunaryono ${ }^{1}$ \\ ${ }^{1}$ Pendidikan Fisika-Universitas Negeri Malang
}

\section{INFO ARTIKEL}

\section{Riwayat Artikel:}

Diterima: 03-07-2019

Disetujui: 16-01-2020

Kata kunci:
conceptual problem solving;
problem solving skill;
ability of representation;
multi-representation;
kemampuan pemecahan masalah;
kemampuan representasi;
multirepresentasi

\section{Alamat Korespondensi:}

Leonardus Hendra Aha

Pendidikan Fisika

Universitas Negeri Malang

Jalan Semarang 5 Malang

E-mail: Leonardushendraaha11@gmail.com

\begin{abstract}
ABSTRAK
Abstract: The purpose of this study is to look at the problem solving abilities and the representation abilities between students who learn with multi-presentation learning strategies with the conceptual problem solving approach and students who learn with conventional learning. Total sample is 68 students selected using the simple random sampling technique. This study used a quasi experimental method with a pretest-posttest control group design. Data was collected using tests, both before treatment and after treatment. The results of the study were differences in problem solving abilities and representation abilities in both classes. In addition, problem solving abilities and representation abilities of students who learn with multi representation learning strategies with conceptual problem solving approaches are higher than students who learn with conventional learning.
\end{abstract}

\begin{abstract}
Abstrak: Penelitian ini bertujuan untuk mengetahui perbedaan kemampuan pemecahan masalah dan kemampuan representasi antara siswa yang belajar dengan strategi pembelajaran multirepresentasi dengan pendekatan conceptual problem solving dan siswa yang belajar dengan pembelajaran konvensional. Sampel dalam penelitian ini berjumlah 68 siswa yang dipilih dengan teknik simple random sampling. Penelitian ini merupakan penelitian kuantitatif dengan metode eksperimen kuasi. Desain dalam penelitian ini adalah pretest-posttest control group design. Data dikumpulkan dengan menggunakan tes, baik sebelum perlakuan maupun setelah perlakuan. Hasil penelitian terdapat perbedaan kemampuan pemecahan masalah dan kemampuan representasi siswa yang belajar dengan strategi pembelajaran multirepresentasi dengan pendekatan conceptual problem solving dan siswa yang belajar dengan pembelajaran konvensional. Selain itu, kemampuan pemecahan masalah dan kemampuan representasi siswa yang belajar dengan strategi pembelajaran multirepresentasi dengan pendekatan conceptual problem solving lebih tinggi dari siswa yang belajar dengan pembelajaran konvensional.
\end{abstract}

Dalam mempelajari fisika, memecahkan masalah menjadi salah satu faktor penting bagi siswa (Docktor \& Mestre, 2014; Ibrahim \& Rebello, 2012). Pemecahan masalah dibutuhkan oleh siswa untuk memecahkan berbagai persoalan fisika serta dalam mempelajari konsep fisika (Buteler \& Coleoni, 2016). Selain itu, dapat membantu siswa untuk mengkaitkan beberapa hal seperti memahami, serta menguasai konsep, prinsip, teori dan hukum dalam fisika (Sagala, Rahmatsyah, \& Simanjuntak, 2017). Beberapa prosedur pemecahan masalah dalam fisika, seperti bagaimana masalah ditafsirkan atau dipahami, memiliki rencana sesuai solusi masalah, memilih masalah yang paling tepat (persamaan, konsep dan fakta) serta bagaimana setiap variabel diperhatikan sesuai dengan masalah. Prosedur tersebut membantu siswa untuk menemukan arah untuk menyelesaikan masalah (Heller, n.d.). Dalam menyelesaikan masalah, kemampuan siswa dinilai dengan sebuah rubrik yang dikembangkan Docktor (Docktor et al., 2016). Rubrik tersebut terdiri dari lima indikator, yaitu (1) Useful description, (2) Physics approach, (3) Spesific application of physics, (4) Math procedures, (5) Logical progression (Doctor et ). Skor untuk setiap indikator dinilai dari 0 (terburuk) sampai 5 (terbaik). Selain itu, terdapat tambahan kategori not applicable (NA) baik untuk masalah dan siswa (pemecah). NA (problem) menunjukkan bahwa kategori yang dituliskan tidak teridentifikasi atau tidak diperiksa dalam soal. NA (solver) menunjukkan bagaimana keputusan siswa tidak dituliskan dalam pemecahan masalah (Docktor et al., 2016). 
Beberapa penelitian sebelumnya mengidentifikasi kesulitan-kesulitan siswa dalam memecahkan masalah, yaitu (1) siswa memiliki kesulitan dengan konsep yang tidak familiar (Soong, Mercer, \& Er, 2009), (2) siswa menggunakan persamaan matematis tanpa mempedulikan konsep fisika yang digunakan (Snetinova \& Koupilova, 2012), (3) siswa langsung menggunakan persamaan pada materi gerak tanpa menganalisis gerakan benda (Tms \& Sirait, 2016). Pada topik usaha dan energi siswa juga kesulitan dalam memecahkan maslah seperti siswa hanya dibiasakan menggunakan persamaan matematis dalam menyelesaikan masalah tanpa mempelajari penggunaan representasi lainnya, sehingga kemampuan pemecahan masalah siswa rendah (Nikat \& Latifah, 2017). Selain itu, siswa mengalami kesulitan dalam representasi saat pemecahan masalah (Sujarwanto, Hidayat, \& Wartono, 2014). Kesulitan-kesulitan siswa dalam pemecahan masalah ini, salah satunya disebabkan karena kurangnya pengetahuan siswa tentang cara menggunakan representasi (Nguyen, Gire, \& Rebello, 2010). Oleh karena itu, kemampuan representasi dalam menyelesaikan masalah mestinya dibelajarkan bagi siswa.

Representasi dapat diterapkan dalam pembelajaran dengan menggunakan strategi pembelajaran multirepresentasi. Multirepresentasi merupakan model yang mempresentasi beberapa konsep yang sama dalam beberapa format (Angell, Kind, Henriksen, \& Guttersrud, 2008). Dalam fisika, format representasi dapat berupa kata, diagram, gambar, grafik serta persamaan matematika (Rosengrant, Etkina, \& Van Heuvelen, 2007). Multirepresentasi atau representasi majemuk (konsep, diagram, grafik dan rumus), sangat dibutuhkan untuk menggambarkan informasi dalam memahami konsep ilmiah serta pemecahan masalah (Docktor \& Mestre, 2014; Nieminen, Savinainen, \& Viiri, 2010). Dalam pembelajaran, Ainsworth (2008) menyatakan representasi berfungsi sebagai peran pelengkap, sebagai pembatas interpretasi serta sebagai sarana untuk membangun pemahaman lebih lengkap (FISKE, 2010). Dalam pembelajaran fisika, multirepresentasi harus disertakan dalam mengimplementasikan pendekatan pemodelan, hal ini dikarenakan dua alasan utama, yaitu (1) dalam sains model didefinisikan sebagai representasi dari realita sehingga dapat digunakan untuk membangun pemahaman siswa dalam mempelajari sains sebagai sebagai ilmu alam, (2) model dan pemodelan sangat baik digunakan sebagai sarana dalam mengajari dan mempelari fisika dengan penggunaan multirepresentasi (Angell et al., 2008). Strategi pembelajaran multirepresentasi dalam pembelajaran terdiri atas empat fase, yaitu orientasi, eksplorasi, internalisasi, dan evaluasi (Yuanita \& Ibrahim, 2015). Beberapa hasil penelitian menyatakan bahwa penggunaan pembelajaran multirepresentasi dapat meningkatan kemampuan representasi, penguasaan konsep serta pemecahan masalah (Abdurrahman, Liliasari, Rusli, \& Waldrip, 2011; De Cock, 2012; Doyan, Taufik, \& Anjani, 2018; Sujarwanto et al., 2014; Sutopo, 2013).

Selain itu, penggunaan pendekatan conceptual problem solving (CPS) dalam pemecahan masalah sangat dibutuhkan siswa untuk menguasai konsep yang dibutuhkan dalam memecahkan masalah. Pemecahan masalah dengan menggunakan Conceptual Problem Solving (CPS) dilakukan dengan tiga tahap utama yaitu konsep fisika apa yang digunakan, pembenaran dalam penggunaan konsep dan perencanaan yang meliputi penggunaan berbagai representasi (Buteler \& Coleoni, 2016; Docktor, Strand, Mestre, \& Ross, 2015). Penelitian yang dilakukan Docktor, Strand, Mestre dan Ross (2010), dengan melakukan implementasi penggunaan pendekatan conceptual problem solving (CPS) pada empat sekolah berbeda mendapatkan hasil yang baik dalam penguasaan konsep serta pemecahan masalah fisika. Selanjutnya Docktor, Strand, Mestre dan Ross (2015) melakukan kembali penelitian tentang pendekatan conceptual problem solving (CPS) pada tiga sekolah berbeda yaitu sekolah A, B dan C. Secara keseluruhan, siswa mengalami peningkatan dalam memecahkan masalah secara konseptual dibandingkan dengan pendekatan tradisional.

Berdasarkan ulasan tersebut, peneliti melakukan implementasi pendekatan conceptual problem solving (CPS) dalam pembelajaran dengan fokus multirepresentasi. Penelitian ini dilakukan dengan tujuan untuk melihat bagaimana kemampuan siswa dalam menyelesaikan masalah serta representasi dengan menggunakan pembelajaran multirepresentasi disertai pendekatan conceptual problem solving.

\section{METODE}

Penelitian ini menggunakan metode penelitian eksperimen kuasi dengan pretest-posttest control group design. Desain penelitian dapat dilihat pada tabel 1 .

Tabel 1. Rancangan Penelitian Eksperimen Kuasi, Pretest- Posttest Control Group Design

\begin{tabular}{lllll}
\hline Kelas Eksperimen & $\mathrm{R}$ & $\mathrm{O}_{1}$ & & $\mathrm{O}_{2}$ \\
Kelas Kontrol & $\mathrm{R}$ & $\mathrm{O}_{1}$ & $\mathrm{X}$ & $\mathrm{O}_{2}$ \\
\hline
\end{tabular}

Keterangan

$\mathrm{R}$ : Random Assigment

$\mathrm{O}_{1}$ : Pemberian pre-test

$\mathrm{O}_{2}$ : Pemberian post-test

$\mathrm{X}$ : Pembelajaran dengan strategi pembelajaran multirepresentasi dengan pendekatan conceptual problem solving 
Populasi dalam penelitian ini adalah seluruh siswa kelas X SMAK St. Fransiskus Xaverius Ruteng. Teknik pengambilan sampel dengan menggunakan simple random sampling. Sampel dalam penelitian ini terdiri dari dua kelas pada siswa kelas X SMAK St. Fransiskus Xaverius Ruteng. Kelas eksperimen berjumlah 35 orang dan kelas kontrol berjumlah 33 orang. Kemampuan pemecahan masalah dan kemampuan representasi siswa diketahui dengan menggunakan lima soal uraian yang diujikan pada dua tahap yaitu sebelum diberi perlakuan (pretest) dan setelah diberi perlakuan (posttest). Kemampuan pemecahan masalah siswa dinilai dengan rubrik yang dikembangkan Docktor (Docktor et al., 2016) yaitu usefull description, physics approach, spesific application of physics dan math procedures. Kemampuan representasi dinilai dengan menggunakan rubrik skor kemampuan representasi yaitu missing, anadequate, need some improvement dan adequate (Etkina et al., 2006). Data kemampuan pemecahan masalah dan kemampuan representasi dianalisis dengan menggunakan uji normalitas dan homogenitas. Pengujian hipotesis dilakukan dengan menggunakan uji manova, anova dan uji LSD.

\section{HASIL}

\section{Kemampuan Pemecahan Masalah}

Data kemampuan pemecahan masalah diperoleh melalui jawaban siswa baik sebelum dan sesudah perlakuan. Deskripsi data kemampuan pemecahan masalah terdapat pada tabel 2.

Tabel 2. Deskripsi Data Kemampuan Pemecahan Masalah Kelas Eksperimen dan Kelas Kontrol

\begin{tabular}{ccccc}
\hline Statistik & \multicolumn{2}{c}{ Kelas Eksperimen } & \multicolumn{2}{c}{ Kelas Kontrol } \\
\cline { 2 - 5 } & Pretest & Posttest & Pretest & Posttest \\
\hline $\mathrm{N}$ & 35 & 35 & 33 & 33 \\
$\bar{x}$ & 20,029 & 68,88 & 22,81 & 45,54 \\
$S D$ & 8,67 & 8,03 & 9,4 & 11,3 \\
$x_{\min }$ & 3 & 52 & 4 & 24 \\
$x_{\max }$ & 37 & 90 & 56 & 85 \\
\hline
\end{tabular}

Berdasarkan tabel 2 sebelum diberi perlakuan, nilai kemampuan pemecahan masalah kelas eksperimen dan kontrol sebesar 20,029 dan 22,81. Setelah diberi perlakuan, kemampuan pemecahan masalah pada kedua kelas meningkat yaitu 68,88 dan 45,54. Data perbandingan kemampuan pemecahan masalah untuk setiap indikator baik sebelum dan sesudah diberi perlakuan untuk kelas eksperimen dan kelas kontrol terdapat pada gambar 1.

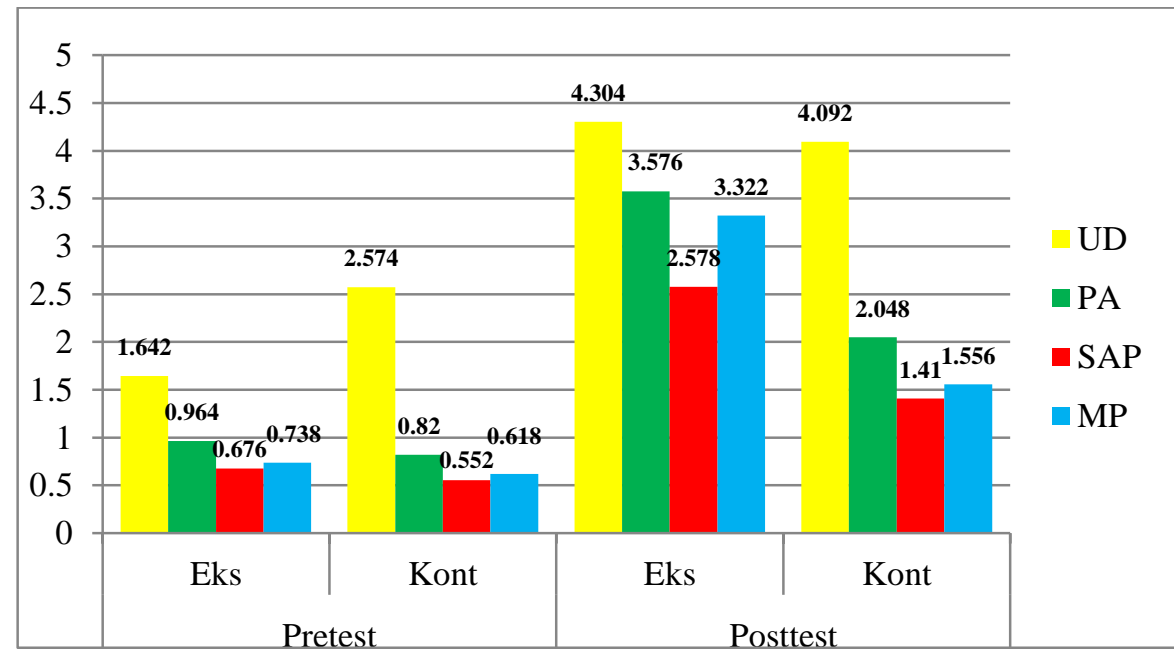

\section{Gambar 1. Grafik Perbandingan Kemampuan Pemecahan Masalah antara Kelas Eksperimen dan Kelas Kontrol}

Berdasarkan gambar 1 sebelum perlakuan diberikan baik pada kelas eksperimen maupun kelas kontrol, kedua kelas mendapatkan nilai kemampuan pemecahan masalah yang berkisar antara 0,552-2,574. Pada indikator useful description kedua kelas mendapatkan nilai sebesar 2,574 (51,48\%) untuk kelas kontrol serta 1,642 (32,84\%) untuk kelas eksperimen. Sedangkan pada tiga indikator lainnya selisih skor antara kelas eksperimen dengan kelas kontrol sangat kecil. Indikator physics approach, kelas eksperimen mendapatkan nilai 0,964 (19,28\%), sedangkan kelas kontrol memperoleh nilai 0,82 (16,4\%). Indikator specific application of physics, kelas eksperimen mendapatkan nilai 0,676 (13,52\%), sedangkan kelas kontrol memperoleh nilai 0,552 (11,04\%). Indikator math procedures, kelas eksperimen mendapatkan nilai 0,738 (14,76\%), sedangkan kelas kontrol memperoleh nilai $0,618(12,36 \%)$. 
Berdasarkan gambar 1 setelah diberi perlakuan, kelas eksperimen mendapatkan skor yang lebih tinggi dibandingkan dengan kelas kontrol. Pada indikator useful description, kelas eksperimen mendapatkan nilai 4,304 (86,08\%) sedangkan kelas kontrol memperoleh nilai 4,092 (81,84\%). Indikator physics approach, kelas eksperimen mendapatkan nilai 3,576 (71,52\%), sedangkan kelas kontrol memperoleh nilai 2,048 (40,96\%). Indikator specific application of physics, kelas eksperimen mendapatkan nilai 2,578 (51,56\%) sedangkan kelas kontrol memperoleh nilai 1,41 (28,2\%). Indikator math procedures, kelas eksperimen mendapatkan nilai 3,322 (66,44\%), sedangkan kelas kontrol memperoleh nilai 1,556 (31,12\%). Berdasarkan hasil skor tersebut terlihat bahwa pada indikator useful description siswa pada kedua kelas berada pada kategori deskripsi berguna, tetapi mengandung beberapa error atau data yang hilang. Pada indikator physics approach, kemampuan pemecahan masalah kelas eksperimen dengan kategori pendekatan fisika mengandung beberapa kesalahan, sedangkan kelas kontrol berada pada kategori kebanyakan pendekatan fisika hilang atau tidak tepat. Pada indikator spesific application of physics, kemampuan pemecahan masalah kelas eksperimen dengan kategori sebagian penerapan spesifik dalam fisika mengandung beberapa error, sedangkan kelas kontrol berada pada kategori keseluruhan penerapan spesifik dalam fisika tidak tepat atau mengandung beberapa error. Pada indikator math procedures, kemampuan pemecahan masalah kelas eksperimen dengan kategori sebagian prosedur matematika mengandung beberapa error, sedangkan kelas kontrol berada pada kategori keseluruhan prosedur matematika tidak tepat atau mengandung beberapa error.

\section{Data Kemampuan Representasi}

Data kemampuan representasi diperoleh melalui jawaban siswa baik sebelum dan sesudah perlakuan. Deskripsi data kemampuan representasi kelas eksperimen dan kelas kontrol terdapat pada tabel 3.

Tabel 3. Deskripsi Data Kemampuan Representasi Kelas Eksperimen dan Kelas Kontrol

\begin{tabular}{lcccc}
\hline \multirow{2}{*}{ Statistik } & \multicolumn{2}{c}{ Kelas Eksperimen } & \multicolumn{2}{c}{ Kelas Kontrol } \\
\cline { 2 - 5 } & Pretest & Posttest & Pretest & Posttest \\
\hline $\mathrm{N}$ & 35 & 35 & 33 & 33 \\
$\bar{x}$ & 4,54 & 13,71 & 3,73 & 7,73 \\
$\boldsymbol{x}$ & & & & \\
SD & 2,23 & 2,82 & 2,21 & 2,98 \\
$x_{\min }$ & 1 & 8 & 1 & 4 \\
$x_{\max }$ & 10 & 23 & 10 & 20 \\
\hline
\end{tabular}

Berdasarkan tabel 3, sebelum diberi perlakuan, nilai kemampuan representasi kelas eksperimen dan kontrol sebesar 4,53 dan 3,73. Setelah diberi perlakuan, terjadi peningkatan kemampuan representasi pada kedua kelas yaitu 13,71 dan 7,73. Data perbandingan kemampuan representasi untuk setiap indicator terdapat pada gambar 2.

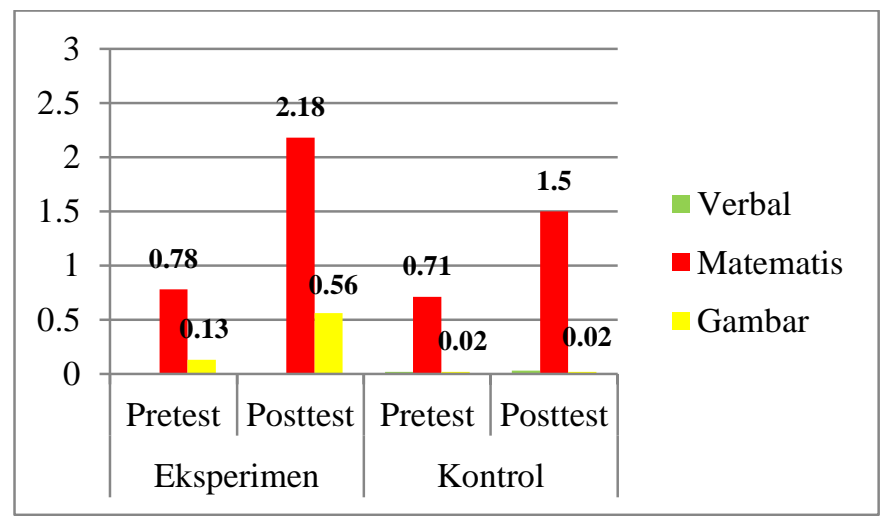

\section{Gambar 2. Grafik Perbandingan Kemampuan Representasi antara Kelas Eksperimen dan Kontrol}

Berdasarkan gambar 2, terlihat bahwa sebelum perlakuan diberikan, kedua kelas mendapatkan nilai pada setiap indikator kemampuan representasi berkisar antara 0,02-0,78. Pada representasi gambar, kelas eksperimen mendapatkan nilai, 0,013 dan 0,02 untuk kelas kontrol. Hal ini mengindikasikan bahwa kemampuan representasi gambar kedua kelas masih berada di level missing yaitu tidak terdapat representasi gambar yang dibuat. Pada representasi verbal, kedua kelas mendapatkan nilai 0, dan berada pada level missing yaitu tidak terdapat representasi verbal yang dibuat. Pada representasi matematis, kelas eksperimen mendapatkan nilai, 0,78 dan 0,71 untuk kelas kontrol. Representasi matematis kedua kelas berada pada level inadequate yaitu representasi matematis yang ditulis memuat konsep yang salah, langkah-langkah tidak jelas serta besaran fisis tidak benar. 
Setelah diberi perlakuan, representasi gambar dan matematis untuk kelas eksperimien meningkat, sedangkan kelas kontrol hanya terdapat peningkatan pada representasi matematis. Kemampuan representasi verbal kedua kelas tidak meningkat yakni masih berada dilevel yang sama seperti sebelumnya. Kemampuan representasi gambar kelas eksperimen mendapatkan nilai, 0,56 dan 0,03 untuk kelas kontrol. Kemampuan representasi gambar pada kelas eksperimen berada pada level inadequate yaitu terdapat gambar, tetapi kurang lengkap tanpa besaran fisis atau informasi yang dimuat salah. Pada kelas kontrol masih berada pada level missing yaitu tidak terdapat representasi yang dibuat. Kemampuan representasi matematis pada kelas eksperimen dan kontrol mendapatkan nilai 2,18 an 1,5. Pada kelas eksperimen, kemampuan representasi matematis berada pada level need some improvement yaitu penggunaan representasi matematis tepat, tidak terdapat kesalahan dalam penalaran, tetapi tidak sepenuhnya dapat menyelesaikan langkah-langkah dalam menyelesakan persoalan. Pada kelas kontrol, kemampuan representasi matematis berada pada level inadequate yaitu representasi matematis yang ditulis memuat konsep yang salah, langkah-langkah tidak jelas serta besaran fisis tidak benar. Data kemampuan pemecahan masalah dan kemampuan representasi kemudian diuji normalitas menggunakan uji Liliefors dan uji homogenitas menggunakan uji Bartlett. Hasilnya terdapat pada tabel 4 dan 5.

Tabel 4. Uji Normalitas Data Kemampuan Pemecahan Masalah dan Kemampuan Representasi

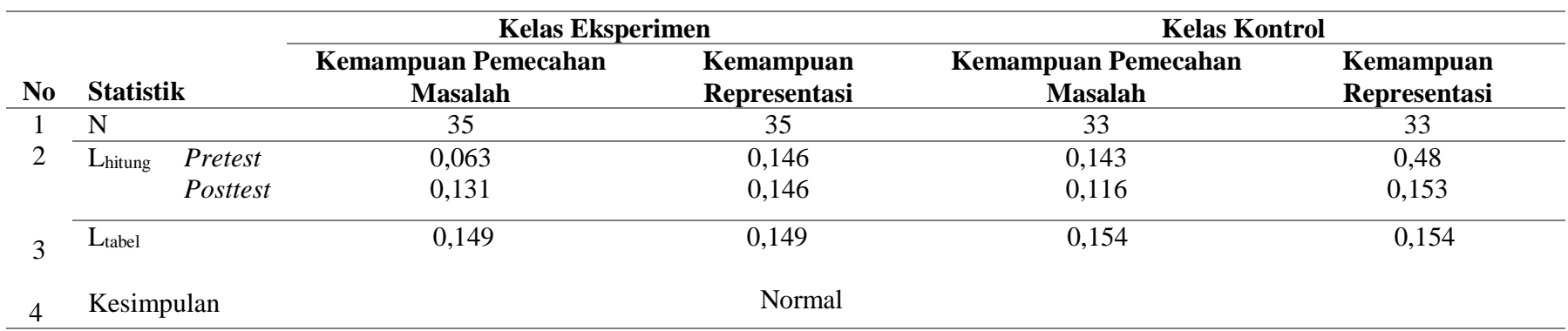

Tabel 5. Uji Homogenitas Data Kemampuan Pemecahan Masalah dan Kemampuan Representasi

\begin{tabular}{|c|c|c|c|}
\hline No & Statistik & Kemampuan Pemecahan Masalah & Kemampuan Representasi \\
\hline \multirow{3}{*}{$\begin{array}{l}1 \\
2\end{array}$} & $\mathrm{~N}$ & 68 & 68 \\
\hline & Pretest & 0,215 & 0,0265 \\
\hline & Posttest & 3,785 & 0,1 \\
\hline 3 & $\chi_{t}^{2}$ & 3,84 & 3,84 \\
\hline 4 & Kesimpulan & Homog & \\
\hline
\end{tabular}

Selanjutnya dilakukan uji kesamaan kemampuan awal, uji one way manova, one way anova dan uji lanjut LSD. Uji kesamaan kemampuan awal menggunakan uji one way anova pada data hasi tes kemampuan pemecahan masalah dan kemampuan representasi siswa sebelum perlakuan diberikan. Uji one way manova, one way anova dan uji lanjut LSD menggunakan data hasil tes kemampuan pemecahan masalah dan kemampuan representasi siswa setelah diberikan perlakuan. Hasil uji kesamaan kemampuan awal, one way manova, one way anova dan uji lanjut LSD dapat dilihat pada tabel 6, 7, 8 dan 9.

\section{Tabel 6. Uji Kesamaan Kemampuan Awal Kemampuan Pemecahan Masalah dan Kemampuan Representasi Siswa}

\begin{tabular}{llll}
\hline \multicolumn{1}{c}{ Interaksi } & \multicolumn{1}{c}{ Variabel } & Fhitung & F tabel \\
\hline Pembelajaran Multirepresentasi dengan & Kemampuan Pemecahan Masalah & 1,62 & 3,99 \\
Pendekatan Conceptual Problem & Kemampuan Representasi & 2,292 & 3,99 \\
Solving vs Pembelajaran Konvensioanl & & & \\
\hline
\end{tabular}

Berdasarkan tabel 6 dapat dilihat bahwa pada semua interaksi, $\mathrm{F}_{\text {hitung }}<\mathrm{F}_{\text {tabel }}$, maka hipotesis $\mathrm{H}_{0}$ diterima. Dengan demikian, untuk hipotesis lainnya ditolak yaitu (a) tidak terdapat perbedan kemampuan pemecahan masalah antara siswa yang belajar dengan strategi pembelajaran multirepresentasi dengan pendekatan conceptual problem solving dan siswa yang belajar dengan pembelajaran konvensional sebelum diberi perlakuan dan (b) tidak terdapat perbedaan kemampuan representasi awal antara siswa yang belajar dengan strategi pembelajaran multirepresentasi dengan pendekatan conceptual problem solving dan siswa yang belajar dengan pembelajaran konvensional sebelum diberi perlakuan. 
Tabel 7. Hasil Uji One Way Manova

\begin{tabular}{cccc}
\hline Hasil Pengujian & Nilai Hitung & Nilai Tabel & Keterangan \\
\hline Wilks Lambda & 0,396 & 0,903 & Ada perbedaan \\
$F$ & 49,646 & 3,99 & \\
\hline
\end{tabular}

Berdasarkan tabel 7, wilks lambda hitung sebesar 0,396 dengan nilai wilks lambda tabel sebesar 0,903 sehingga

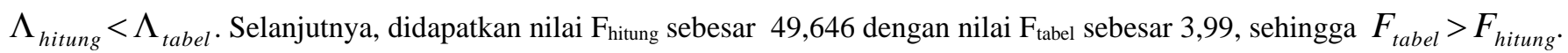
Hasil pengujian bahwa hipotesis $\mathrm{H}_{0}$ tidak diterima sehingga terdapat perbedaan kemampuan pemecahan masalah dan kemampuan representasi antara siswa yang belajar dengan strategi pembelajaran multirepresentasi dengan pendekatan conceptual problem solving dan siswa yang belajar dengan pembelajaran konvensional.

Tabel 8. Hasil One Way Anova untuk Kemampuan Pemecahan Masalah dan Kemampuan Representasi

\begin{tabular}{llll}
\hline Interaksi & Variabel & $\mathbf{F}_{\text {hitung }}$ & $\mathbf{F}_{\text {tabel }}$ \\
\hline Pembelajaran Multirepresentasi dengan & Kemampuan Pemecahan Masalah & 97,25 & 3,99 \\
$\begin{array}{l}\text { Pendekatan Conceptual Problem Solving } \\
\text { vs Pembelajaran Konvensioanl }\end{array}$ & Kemampuan Representasi & 72,31 & 3,99 \\
\hline
\end{tabular}

Berdasarkan tabel 8 dapat dilihat bahwa pada semua interaksi, $F_{\text {hitung }}>F_{\text {tabel, }}$ sehingga (a) terdapat perbedaan kemampuan pemecahan masalah antara siswa yang belajar dengan strategi pembelajaran multirepresentasi disertai pendekatan conceptual problem solving dan siswa yang belajar dengan pembelajaran konvensional; (b) terdapat perbedaan kemampuan representasi antara siswa yang belajar dengan strategi pembelajaran multirepresentasi disertai pendekatan conceptual problem solving dan siswa yang belajar dengan pembelajaran konvensional.

Tabel 9. Hasil Uji LSD

\begin{tabular}{llll}
\hline \multicolumn{1}{c}{ Interaksi } & \multicolumn{1}{c}{ Variabel } & $\left|\overline{X_{1}}-\overline{X_{2}}\right|$ & \multicolumn{1}{c}{$\boldsymbol{L S D}$} \\
\hline $\begin{array}{l}\text { Pembelajaran Multirepresentasi dengan } \\
\text { Pendekatan Conceptual Problem Solving } \\
\text { vs Pembelajaran Konvensioanl }\end{array}$ & Kemampuan Pemecahan Masalah & 23,34 & 4,71 \\
& & 5,99 & 1,4 \\
\hline
\end{tabular}

Berdasarkan Tabel 9 dapat dilihat bahwa untuk semua interaksi $\left|\overline{X_{1}}-\overline{X_{2}}\right|=23,34 ; 5,99>L S D=4,71 ; 1,4$ sehingga (a) kemampuan pemecahan masalah siswa yang belajar dengan strategi pembelajaran multirepresentasi disertai pendekatan conceptual problem solving lebih tinggi dari siswa yang belajar dengan pembelajaran konvensional; (b) kemampuan representasi siswa yang belajar dengan strategi pembelajaran multirepresentasi disertai pendekatan conceptual problem solving lebih tinggi dari siswa yang belajar dengan pembelajaran konvensional.

\section{PEMBAHASAN}

Kemampuan pemecahan masalah dan kemampuan representasi diketahui dengan menggunakan soal uraian sebanyak lima nomor baik sebelum diberi perlakuan (pretest) maupun setelah diberi perlakuan (posttest). Kelas eksperimen diberi perlakuan berupa strategi pembelajaran multirepresentasi disertai pendekatan conceptual problem solving, sedangkan kelas kontrol diberi perlakuan berupa pembelajaran konvensional.

Data kemampuan pemecahan masalah dan kemampuan representasi sebelum diberikan perlakuan menunjukkan nilai yang rendah untuk masing-masing kelas. Kemampuan pemecahan masalah kelas eksperimen mendapatkan nilai 20,029 dan kemampuan representasi 4,54. Kelas kontrol mendapatkan nilai kemampuan pemecahan masalah 22,81 dan kemampuan representasi 3,73. Data pretest kemudian diuji menggunakan uji kemampuan awal dengan one way anova dan didapatkan bahwa kemampuan pemecahan masalah dan kemampuan representasi kedua kelas adalah sama. Setelah diberi perlakuan, kemampuan pemecahan masalah dan kemampuan representasi untuk masing-masing kelas meningkat. Nilai kemampuan pemecahan masalah dan kemampuan representasi kelas eksperimen sebesar 68,88 dan 13,71. Nilai kemampuan pemecahan masalah dan kemampuan representasi untuk kelas kontrol sebesar 45,54 dan 7,73.

Berdasarkan uji one way manova didapatkan bahwa adat perbedaan kemampuan pemecahan masalah dan kemampuan representasi secara simultan antara kedua kelas. Selanjutnya, dilakukan uji one way anova dan hasilnya menunjukkan bahwa (1) terdapat perbedaan kemampuan pemecahan masalah pada kedua kelas, (2) terdapat perbedaan kemampuan representasi pada kedua kelas. Setelah diketahui ada perbedaan pada masing-masing variabel dependent, maka dilakukan uji lanjut ( $L S D)$. Hasil uji lanjut ( $L S D$ ) bahwa (1) kemampuan pemecahan masalah siswa kelas eksperimen lebih tinggi dari kelas kontrol, (2) kemampuan representasi siswa kelas eksperimen lebih dari siswa kelas kontrol. 
Perbedaan kemampuan pemecahan masalah dan kemampuan representasi pada kedua kelas dikarenakan pengaruh perlakuan yang diberikan. Pembelajaran kelas eksperimen, setiap tahap pembelajaran siswa diberi fenomena-fenomena berupa konsep fisika. Fenomena-fenomena fisika ini dikenalkan pada siswa dengan beberapa abstraksi yang berbeda baik berupa demonstrasi, verbal ataupun melalui visualisasi (gambar, grafik, dan simulasi). Selain itu, penggunaan pendekatan conceptual problem solving melatih siswa menyelesaikan masalah dengan mengidentifikasi konsep serta penggunaan representasi sesuai konsep yang digunakan. Siswa kelas kontrol hanya diberi penjelasan dan dilatih untuk menyelesaikan soal, tanpa ditekankan pada pada penggunaan representasi serta pemecahan masalah secara terstruktur. Disamping itu, siswa hanya mendengarkan penjelasan dari guru.

Kemampuan pemecahan masalah yang tinggi pada kelas eksperimen dikarenakan siswa menggunakan pembelajaran multirepresentasi dengan pendekatan conceptual problem solving. Pembelajaran multirepresentasi membantu siswa untuk mengenali beberapa representasi yang berbeda dalam sebuah konsep yang sama (Carl Angell, 2000). Selain itu penggunaan pendekatan conceptual problem solving membiasakan siswa untuk menggunakan konsep yang tepat dalam memecahkan masalah serta membantu siswa memecahkan masalah dengan prosedur atau langkah-langkah yang sistematis. Sedangkan siswa pada kelas kontrol hanya diberi penjelasan serta mempelajari persamaan yang ada tanpa diberi penekanan pada penggunaan konsep serta memecahkan masalah yang terstruktur. Efektivitas memecahkan masalah dimulai dengan analisis konseptual masalah, perencanaan solusi, implementasi serta evaluasi dan refleksi proses pemecahan masalah (Singh, 2009). Hasil ini sesuai dengan penelitian-penelitian lain yang menyatakan penggunaan multirepresentasi mebantu meningkatkan hasil belajar serta penguasaan konsep dalam pemecahan masalah (Abdurrahman et al., 2011; Doyan et al., 2018). Selain itu, penggunaan pendekatan conceptual problem solving membantu siswa dalam memecahkan masalah dengan lebih baik dibandingkan pendekatan tradisional (Docktor et al., 2015).

Kemampuan representasi yang tinggi pada kelas eksperimen disebabkan siswa selalu dikenali dengan beberapa representasi baik verbal, matematis maupun gambar. Selain itu, siswa dalam menyelesaikan masalah harus memuat konsep yang dipilih serta merepresentasikannya. Pada kelas kontrol siswa hanya ditekankan pada penggunaan representasi matematis dalam pembelajaran dan penyelesaian masalah. Hasil ini sesuai dengan penelitian Sutopo yang menunjukkan pembelajaran multirepresentasi mampu meningkatkan kemampuan representasi siswa (Sutopo, 2013).

\section{SIMPULAN}

Hasil penelitian menunjukan ada perbedaan KPM dan kemampuan representasi pada kedua kelas di mana kemampuan pemecahan masalah dan kemampuan representasi siswa yang belajar dengan strategi pembelajaran multirepresentasi dengan pendekatan conceptual problem solving lebih tinggi dari siswa yang belajar dengan pembelajaran konvensional. Saran untuk penelitian selanjutnya untuk meninjau kemampuan penguasaan konsep siswa sebagai pengaruh dari pembelajaran multirepresentasi dengan pendekatan conceptual problem solving.

\section{DAFTAR RUJUKAN}

Abdurrahman., Liliasari., Rusli, A., \& Waldrip, B. (2011). Implementasi Pembelajaran Berbasis Multi Representasi untuk Peningkatan Penguasaan Konsep Fisika Kuantum. Cakrawala Pendidikan, 30(1), 30-45. https://doi.org/10.21831/cp.v1i1.4189

Angell, C. (2000). Multiple Representations as a Framework for a Modelling Approach to Physics Education. International Journal, 1-4.

Buteler, L., \& Coleoni, E. (2016). Solving Problems to Learn Concepts, How Does it Happen? A Case for Buoyancy. Physical Review Physics Education Research, 12(2), 1-12. http://doi.org/10.1103/PhysRevPhysEducRes.12.020144

De Cock, M. (2012). Representation Use and Strategy Choice in Physics Problem Solving. Physical Review Special Topics Physics Education Research, 8(2), 1-15. https://doi.org/10.1103/PhysRevSTPER.8.020117

Docktor, J. L., Strand, N. E., Mestre, J. P., \& Ross, B. H. (2010). A Conceptual Approach to Physics Problem Solving. AIP Conference Proceedings, 1289, 137-140. https://doi.org/10.1063/1.3515180

Docktor, J. L., \& Mestre, J. P. (2014). Synthesis of Discipline-Based Education Research in Physics. Physical Review Special Topics - Physics Education Research, 10(2), 1-58. https://doi.org/10.1103/PhysRevSTPER.10.020119

Docktor, J. L., Strand, N. E., Mestre, J. P., \& Ross, B. H. (2015). Conceptual Problem Solving in High School Physics. Physical Review Special Topics - Physics Education Research, 11(2),1-13. https://doi.org/10.1103/PhysRevSTPER.11.020106

Docktor, J. L., Dornfeld, J., Frodermann, E., Heller, K., Hsu, L., Jackson, K. A., \& Yang, J. (2016). Assessing Student Written Problem Solutions: A Problem Solving Rubric with Application to Introductory Physics. Physical Review Physics Education Research, 12(1), 1-18. https://doi.org/10.1103/PhysRevPhysEducRes.12.010130

Doyan, A., Taufik, M., \& Anjani, R. (2018). Pengaruh Pendekatan Multi Representasi terhadap Hasil Belajar Fisika Ditinjau dari Motivasi Belajar Peserta Didik. Jurnal Penelitian Pendidikan IPA, 4(1), 35- 45. https://doi.org/10.29303/jppipa.v4i1.99

Etkina, E., Van Heuvelen, A., White-Brahmia, S., Brookes, D. T., Gentile, M., Murthy, S., ...Warren, A. (2006). Scientific Abilities and Their Assessment. Physical Review Special Topics - Physics Education Research, 2(2), 1-15. https://doi.org/10.1103/PhysRevSTPER.2.020103 
Fiske, W. A. (2010). The Educational Value of Physics. School Science and Mathematics, 1(9), 455-463. https://doi.org/10.1111/j.1949-8594.1902.tb00125.x

Gall, M. D \& Borg, W. R. (2003). Educational Research: An Introduction ( $\left.7^{\text {th }} e d\right)$. New Work: Longman, Inc.

Guttersturd, O., \& Angell, C. (2008). Mathematics in Physics: Upper Secondary Physics Students' Competency to Describe Phenomena Applying Mathematical and Graphical Representations.

Heller, K. (2013). Helping Your Students Develop Expertise in Problem Solving - While Learning Physics. USA: University of Minnesota, AAPT New Faculty Workshop.

Ibrahim, B \& Rebello, N. S. (2012). Representational Task Formats and Problem Solving Strategies in Kinematics and Work. Physical Review Special Topics - Physics Education Research, 1-19. https://Doi.Org/10.1103/Physrevstper.8.010126

Nguyen, D. H., Gire, E., \& Rebello, N. S. (2010). Facilitating Students' Problem Solving Across Multiple Representations in Introductory Mechanics. AIP Conference Proceedings, 1289, 45-48. https://doi.org/10.1063/1.3515244

Nieminen, P. Savinainen A, \& Viiri, A. (2010). Erratum: Force Concept Inventory-Based Multiple-Choice Test for Investigating Students Representational Consistency. Physical Review Special Topic Physics Education Research, 6(2), 1-12.

Nikat, R. F, Parno, \& Latifah, E. (2017). Profil Kemampuan Pemecahan Masalah Peserta Didik pada Materi Usaha dan Energi. Prosiding Seminar Nasional Pendidikan IPA Pascasarjana UM. Vol. 2. 2017. ISBN 978-602-9286-22-9

Rosengrant, D., Etkina, E., \& Van Heuvelen, A. (2007). An Overview of Recent Research on Multiple Representations. AIP Conference Proceedings, 883(January 2007), 149-152. https://doi.org/10.1063/1.2508714

Sagala, N. L., Rahmatsyah, \& Simanjuntak, M. P. (2017). The Influence of Problem Based Learning Model on Scientific Process Skill and Problem Solving Ability of Student. IOSR Journal of Research \& Method in Education, 7(4), 1-9. https://doi.org/10.9790/7388-0704040109

Singh, C. (2009). Problem Solving and Learning. AIP Conference Proceedings, 1140, 183-197. https://doi.org/10.1063/1.3183522

Snetinova, M., \& Koupilova, Z. (2012). Students' Difficulties in Solving Physics Problems. WDS'12 Proceedings of Contributed Papers, 93-97.

Soong, B., Mercer, N., \& Er, S. S. (2009). Students' Difficulties When Solving Physics Problems: Results from an ICT-Infused Revision Intervention. Proceedings of the $17^{\text {th }}$ International Conference on Computers in Education, 361-365.

Sujarwanto, E., Hidayat, A., \& Wartono. (2014). Kemampuan Pemecahan Masalah Fisika pada Modeling Instruction pada Siswa SMA Kelas XI. Jurnal Pendidikan IPA Indonesia, 3(1), 65-78. http://doi.org/10.15294/jpii.v3i1.2903

Sunyono, Yuanita, L., \& Ibrahim, M. (2015). Supporting Students in Learning with Multiple Representation to Improve Student Mental Models on Atomic Structure Concepts. Science Education International, 26(2), 104-125.

Sutopo. (2013). Meningkatkan Kemampuan Representasi dan Kecakapan Generik Sains Mahasiswa melalui Pendekatan Representasional. Jurnal Ilmu Pendidikan, 19(2009), 7-16.

Theasy, Y, Wijayanto., \& Sujarwata. (2017). Identifikasi Kesulitan Belajar Fisika Berdasarkan Kemampuan Multirepresentasi. Journal of Physics Communication, 1(2), 1-5.

TMS, H., \& Sirait, J. (2016). Representations Based Physics Instruction to Enhance Students' Problem Solving. American Journal of Educational Research, 4(1), 1-4. https://doi.org/10.12691/education-4-1-1 